DOI 10.37882/2223-2974.2021.05-2.01

\title{
ФЕДЕРАЛЬНОЕ И РЕГИОНАЛЬНОЕ ЗАКОНОДАТЕЛЬСТВО ОБ АДМИНИСТРАТИВНЫХ ПРАВОНАРУШЕНИЯХ: ПРОБЛЕМЫ СООТНОШЕНИЯ
}

\section{FEDERAL AND REGIONAL LEGISLATION ON ADMINISTRATIVE OFFENSES: PROBLEMS OF CORRELATION}

Ya. Vasileva

Summary: The relevance of the research topic is related to the most important problem for the state - the problem of reforming the legislation on administrative offenses. Currently, scientists and practitioners offer their solutions to improve this type of legislation and criticize a number of its modern provisions, which were born as a result of numerous attempts by the legislator to make various changes due to the changed circumstances in the state and socio-political life of Russia. The article deals with the main issues of the correlation of legislation on administrative offenses at the federal and regional levels.

Keywords: legislation on administrative offenses, administrative responsibility.
$\Pi$ редупреждение совершения административных правонарушений, привлечение виновных лиц к административной ответственности, своевременная актуализация положений административно-деликтного законодательства затрудняется в настоящее время по ряду причин.

Первая - это нестабильность и постоянно вносящиеся поправки и дополнения в федеральный акт. Только за 2019-2020 годы изменения в КоАП РФ были внесены 79 федеральными законами, которыми введено множество новых составов административных правонарушений в различных сферах: санитарно-эпидемиологического благополучия населения, информационной безопасности, валютного регулирования, общественного порядка, охраны окружающей среды, транспортной безопасности, обращения лекарственных средств и других. Субъекты РФ в буквальном смысле не успевают за изменениями законодательства на федеральном уровне. Введение запретов, формирование новых составов административных правонарушений в КоАП РФ влечет внесение изменений в региональные акты, что представляет огромную работу законодательных и исполнительных органов власти субъектов РФ. Вследствие этого, административно-деликтные законы «худеют», в виду устранения дублированных составов федерального и регионального уровней, а также весьма стремительно

\author{
Васильева Яна Валерьевна \\ К.ю.н., доцент, Северо-Западный институт (филиал) \\ Университета имени О.Е. Кутафина (МГЮА), г. Вологда \\ yana.vasileva@list.ru
}

Аннотация: Актуальность темы исследования связана с важнейшей для государства проблемой - проблемой реформирования законодательства 06 административных правонарушениях. В настоящее время ученые и практики предлагают свои решения по совершенствованию данного вида законодательства и критикуют ряд его современных положений, появившихся на свет в результате многочисленных попыток законодателя внести различного рода изменения ввиду изменившихся обстоятельств в государственной и общественно-политической жизни России. В статье рассматриваются основные вопросы соотношения законодательства $0 б$ административных правонарушениях на федеральном и региональном уровнях.

Ключевые слова: законодательство об административных правонарушениях, административная ответственность.

утрачивают силу подзаконные акты, которые составляют организационную основу производства. Также следует отметить, что возникновение на федеральном уровне новых административных запретов, а, соответственно, наполнение Особенной части КоАП РФ новыми составами происходит, в большинстве случаев, без учета их регулирующего воздействия на социально-культурную и экономическую сферы отдельных регионов России, которые отличаются многонациональностью, дифференциацией климатических, природно-геологических, финансово-экономических, демографических условий и уровнем развития.

Вторая - несогласованность действий органов исполнительной власти федерального и регионального уровней, что проявляется при заключении соответствующих соглашений между указанными органами публичной власти о передаче соответствующих полномочий. Так, до настоящего времени соглашения между Министерством внутренних дел РФ и высшими органами исполнительной власти субъектов РФ о передаче части полномочий по составлению протоколов об административных правонарушениях, посягающих на общественный порядок и общественную безопасность, предусмотренных законом субъекта РФ, заключены не у всех регионов. Соответственно, ежегодно продлевается срок передачи отдельным органам исполнительной 
государственной власти субъекта РФ полномочий по составлению протоколов по таким правонарушениям. Указанное значительно затрудняет и делает невозможной практическую реализацию положений отдельных статей административно-деликтных законов субъектов РФ, «...рискуя оставить их мёртвыми и неработающими на практике, а, следовательно, права граждан - не защищёнными» [1]. Сложившаяся ситуация усугубляется тем, что региональные и муниципальные должностные лица не имеют реальной возможности оперативно и эффективно реализовывать полномочия по составлению таких протоколов. В свою очередь, сотрудник полиции, выявив административное правонарушение, ответственность за которое предусмотрена законом субъекта РФ, и приняв меры к его пресечению, не вправе составить по данному факту протокол об административном правонарушении, что не только приводит к безнаказанности правонарушителей и ставит под угрозу правовые гарантии регулирования общественных отношений, но и значительно подрывает авторитет и доверие граждан ко всем уровням власти.

Третья - это финансовая проблема. Для того чтобы полноценно и качественно выполнять все обязанности, в распоряжении органов государственной власти субъектов РФ и органов местного самоуправления должны находиться имущество, имущественные права, а также средства бюджета. Денежные средства, необходимые органам для осуществления организации производства по делам об административных правонарушениях, ежегодно предусматриваются законом субъекта РФ о бюджете на очередной финансовый год и плановый период. Ежегодно, в соответствии с методикой расчета, местным бюджетам предоставляются субвенции для осуществления отдельных государственных полномочий по созданию административных комиссий и комиссий по делам несовершеннолетних и защите их прав. К сожалению, муниципальные образования часто испытывают недостаток в финансовых ресурсах, а бюджет муниципалитетов исполняется с ощутимым дефицитом, что влечет невозможность выполнения ими всех взятых на себя публичных обязательств. Соответственно, основной задачей чиновников в отношении бюджетных ресурсов является достижение их сбалансированности - распределение и расходование имеющихся средств необходимо производить с учетом их поступлений. Стоит отметить и положительный опыт, с 2020 года на территории Вологодской области изменены принципы финансирования в деятельности административных комиссий и комиссий по делам несовершеннолетних и защите их прав [2]. Финансирование деятельности коллегиальных органов административной юрисдикции увеличено более чем на 9 миллионов рублей, что прогнозирует увеличение количества рассматриваемых ими дел, обеспечение соблюдение принципа неотвратимости наказания и профилактики правонарушений на территории региона.
Развитие регионального законодательства об административных правонарушениях продиктовано жизненно важной потребностью в качественном регулировании общественных отношений, а также их защиты исходя из особенностей социально-экономического развития, географического, демографического, культурологического положения и природно-климатических условий конкретного субъекта РФ.

Региональный законодатель, при установлении административной ответственности за нарушение нормативных правовых актов субъектов РФ и органов местного самоуправления, ограничен пределами действия КоАП РФ. Кроме того, при правовом регулировании различных сфер общественных отношений субъекты РФ также ограничены отраслевым федеральным законодательством.

Нередко нормы, устанавливающие административную ответственность, признаются недействующими, ввиду вмешательства регионального законодателя в компетенцию Федерации. Такая ситуация характерна, например, для сферы благоустройства территории [3]. Закон субъекта РФ устанавливает ответственность за нарушение требований актов органов местного самоуправления к содержанию территории муниципального образования. Однако при правовом регулировании в указанной сфере органы местного самоуправления часто выходят за пределы своей компетенции. В первую очередь это связано с тем, что сфера благоустройства - неопределенная по своему содержанию и границам. Соответственно, требования муниципальных правовых актов могут затронуть вопросы природопользования, экологии, архитектуры, градостроительства и иные, что уже является предметом регулирования федерального центра. Кроме того, большинство административно-деликтных региональных актов имеют нормы, устанавливающие ответственность за размещение транспортных средств на газонах, цветниках и иных территориях, занятых травянистыми растениями, а также детских и спортивных площадках. Этот вопрос неоднократно оспаривался в судебном порядке и очевидно доказано, что общественные отношения, связанные с вопросом размещения источников повышенной опасности, урегулированы федеральным законодательством в области обеспечения безопасности дорожного движения. Указанное выше подтверждает и тот факт, что в Проекте КоАП РФ, подготовленном Минюстом России в 2020 году [4], федеральный законодатель отнес установление административной ответственности за нарушение законов субъектов РФ и муниципальных нормативных правовых актов в области благоустройства территории к своей компетенции. Многие же субъекты РФ, напротив, наполняют административно-деликтный акт новыми составами административных правонарушений в анализируемой сфере. Так, в Вологодской области по 
результатам работы рабочей группы по рассмотрению вопросов в сфере административных правоотношений с участием законодательных и исполнительных органов публичной власти, в целях конкретизации административных составов в сфере благоустройства территории муниципальных образований, в 2020 году установлена административная ответственность за нарушение требований муниципальных правовых актов: к содержанию территорий; к внешнему виду фасадов и ограждающих конструкций, малых архитектурных форм и объектов общественного благоустройства; к организации освещения и озеленения; к размещению детских и спортивных площадок, площадок для выгула животных, парковок и т.д. (статьи 3.1(1) - 3.1 (12) административно-деликтного закона области [5]).

Вопросы модернизации административно-деликтного законодательства и практики его применения являются обоснованно актуальными. Автор предлагает несколько этапов совершенствования состояния регионального законодательства об административных правонарушениях. Первый этап выражается в необходимости расширять перечень охраняемых объектов в субъектах РФ. Для этого следует взаимодействовать с общественными, научными, экспертными организациями с целью изучения истории, географического положения, климата, культуры, агропромышленного комплекса, экономики региона и, своевременно наполнять и расширять закон субъекта РФ об административных правонарушениях новыми составами, отражающими региональную специфику. Так, например, в Новгородской области в 2018 году в сфере общественных отношений по охране окружающей среды установлена административная ответственность за непроведение мероприятий по удалению с земельных участков борщевика Сосновского (статья 3-12 закона области [6]). В 2018 году это растение официально признано сорняком и включено в Отраслевой классификатор сорных растений. Этот факт дал возможность регионам сформировать программы по борьбе с этим ядовитым зонтичным растением. Так, сельские поселения Новгородской области призвали собственников и арендаторов земельных участков, на которых растёт борщевик Сосновского, заняться работой по удалению этого опасного растения. Законодатель также предложил способы истребления растения: химический, механический или агротехнический.

Второй этап: субъектам РФ следует своевременно приводить закон об административных правонарушениях в соответствие с новым федеральным и региональным законодательством. Так, в целях реализации закона Ленинградской области о регулировании розничной продажи электронных систем доставки никотина и оборота никотинсодержащей продукции на территории региона [7], в июле 2017 года установлена административная ответственность за нарушение ограничений в сфере розничной продажи электронных систем доставки никотина несовершеннолетним в Ленинградской области. Указанная норма регионального закона была принята в связи с отсутствием на федеральном уровне соответствующего правового регулирования. В 2020 году статья признана утратившей силу в связи с принятием Федерального закона от 31 июля 2020 года № 303-Ф3 «О внесении изменений в отдельные законодательные акты Российской Федерации по вопросу охраны здоровья граждан от последствий потребления никотинсодержащей продукции» [8], направленного на создание системы государственного регулирования оборота и потребления никотинсодержащей продукции, в том числе, в части установления мер административной ответственности за нарушение установленных запретов. Соответственно, отпала необходимость в законодательном регулировании этого вопроса на уровне субъектов РФ.

Третий этап: региональный законодатель должен актуализировать административно-деликтный акт с учетом формируемой судебной практики. Так, в 2017 году в Закон Архангельской области об административных правонарушениях введена статья 5.4, предусматривающая административную ответственность за нарушение установленного срока оплаты стоимости перемещения на специализированную стоянку задержанного транспортного средства и хранения на данной стоянке указанного источника повышенной опасности. Впоследствии, заместитель прокурора Архангельской области обратился в Архангельский областной суд с административным исковым заявлением о признании недействующей статьи 5.4 административно-деликтного закона области. Оспаривая положения данной статьи, прокурор указывал на превышение предоставленных субъекту РФ полномочий при введении административной ответственности за названное нарушение. Принимая решение о признании недействующими положений статьи 5.4, суд [9] исходил из того, что обязанность оплатить стоимость перемещения и хранения задержанного транспортного средства в сроки, определенные субъектом РФ, установлена частью 11 статьи 27.13 КоАП РФ, следовательно, административная ответственность за ее несвоевременную оплату может быть установлена только федеральным законодателем. Соответственно, на основании решения суда, в октябре 2019 года статья 5.4 исключена из Закона Архангельской области об административных правонарушениях.

Четвертый этап: регионам следует более тщательно отслеживать развитие своего законодательства, своевременно вносить изменения, включая в закон об административных правонарушениях новые составы, соответствующие современному и действующему законодательству региона, и наоборот исключая то, что является не актуальным. Так, в декабре 2020 года на заседании Калининградской городской Думы принят 
Уставный закон субъекта РФ «О внесении изменений в Устав Калининградской области» [10]. Изменения предусматривают исключение из системы органов государственной власти Калининградской области судебного органа - Уставного Суда. Одновременно принят Уставный закон «Об упразднении Уставного Суда Калининградской области...» [11], которым предусматривается ликвидация судебного органа с 1 апреля 2021 года. Указанные изменения согласуются с правовым подходом, складывающимся на федеральном уровне в связи с реализацией поправок к Конституции РФ, который предусматривает исключение конституционных (уставных) судов субъектов РФ из судебной системы России. Представленные новации привели к изменениям в законе об административных правонарушениях Калининградской области [12]. С 1 апреля текущего года утратила силу статья 51 - невыполнение требований Уставного Суда Калининградской области.

Следующим, пятым этапом видится своевременная актуализация субъективных и объективных признаков состава административного правонарушения. Указанное поможет более точным образом квалифицировать деяние правонарушителя и назначить ему меру наказания. Примером представим изменения диспозиции статьи 2.22 административно-деликтного закона Псковской области [13]. Необходимость внесения изменений была обусловлена целями реализации законов о геральдической символике области $[14,15,16]$. Псковская область до 2018 года была единственным регионом, у которого отсутствовал свой флаг и гимн, а используемый герб не соответствовал установленным геральдическим требованиям. В результате трудной кропотливой работы над эскизами основные элементы официальной символики Псковской области были одобрены. Впоследствии Комитет по законодательству и местному самоуправлению Псковского областного Собрания депутатов рассмотрел законодательную инициативу Псковской городской Думы о введении административной ответственности за надругательство над государственной символикой области и муниципальных образований. Кроме того, ранее за незаконные действия по отношению к государственной символике Псковской области могли привлечь к ответственности только физических и должностных лиц, не затрагивая юридических лиц, которые используют государственную символику без надлежащих на то оснований и тем самым вводят граждан в заблуждение. Тем самым в настоящее время нарушение установленного законодательством области порядка официального использования геральдической символики, а также надругательство и проявление иного неуважения к гимну, флагу или гербу Псковской области, влечет за собой привлечение физических, должностных или юридических лиц к административной ответственности и назначение административного наказания в виде предупреждения или штрафа.
Шестым этапом может стать увеличение размера санкций. Так, в соответствии с необходимостью усиления контроля, защиты и рационального использования оленьих пастбищ, а также недопущению ситуации перевыпаса оленей на территории Ненецкого автономного округа, ужесточены санкции для юридических лиц за превышение общей численности поголовья оленей, содержащихся на оленьем пастбище оленеводческого хозяйства, над оленеемкостью пастбища, определенной проектом внутрихозяйственного землеустройства его территории. Ранее штраф для юридических лиц составлял от пяти тысяч до десяти тысяч рублей, размер штрафа увеличен: от тридцати тысяч до ста тысяч рублей соответственно (статья 3.2 окружного закона) [17]. Указанное обусловлено тем, что превышение численности оленей над оленеёмкостью пастбищ неизбежно влечёт за собой ухудшение состояния пастбищ. В результате этого значительные площади оленьих пастбищ выводятся из сельскохозяйственного производства.

И седьмым этапом, воздействующим на роль, качество и процесс развития законодательства субъектов РФ об административных правонарушениях - это совершенствование юридической техники, в частности, соответствие положений регионального закона требованиям правовой определенности, ясности и недвусмысленности правового регулирования. Так, в соответствии с первоначальной редакцией статьи 1.15 закона об административных правонарушениях Вологодской области, установлена административная ответственность за розничную продажу безалкогольных тонизирующих напитков несовершеннолетним (часть 1), а также за розничную продажу безалкогольных тонизирующих напитков в детских, образовательных и медицинских организациях, организациях культуры, на объектах спорта, в местах проведения культурно-массовых мероприятий для детей, подростков и молодежи (часть 2). При этом в случае продажи безалкогольных тонизирующих напитков несовершеннолетним в местах, указанных в части 2 статьи 1.15 закона области, возникала правовая неопределенность в вопросе установления состава административного правонарушения и размера административного штрафа, который различен для указанных составов. Поэтому в закон об административных правонарушениях Вологодской области внесены изменения [18] в целях недопущения конкуренции правовых норм при выявлении административных деликтов, предусмотренных статьей 1.15. Соответственно, принятие закона о внесении изменений в административно-деликтный закон области позволил исключить указанную правовую неопределенность. Таким образом, недостатки регионального нормотворчества могут быть устранены совершенствованием законодательной техники.

Региональное правотворчество представляет необходимое условие сохранения природы федеративного 
государства и служит решению многочисленных проблем, возникающих перед каждым регионом. Существование двухуровневого законодательства не должно служить причиной для возникновения противоречий между Федерацией и ее субъектами и не должно на- рушать принципы единого правового пространства. Дальнейшее развитие административно-деликтного законодательства должно быть направлено на устранение существующих в настоящее время пробелов и противоречий.

\section{ЛИТЕРАТУРА}

1. Евсикова Е.В. Некоторые проблемы привлечения к административной ответственности за правонарушения, посягающие на общественный порядок и общественную безопасность // Актуальные проблемы административного и административно процессуального права [Электронный ресурс]: сборник статей по материалам международной научно-практической конференции (Сорокинские чтения), 27 марта 2020 года / под общ. ред. д-ра юрид. наук, проф. А.И. Каплунова. - Электрон. дан. (3,98 Мб). - СПб.: Санкт-Петербургский университет МВД России, 2020. С. 407.

2. Официальный сайт Законодательного Собрания Вологодской области // [Электронный ресурс]: URL: https://vologdazso.ru/events/165148/ (дата обращения 31.03.2021).

3. Султанов К.А. 06 административной ответственности за правонарушения в сфере благоустройства, устанавливаемой законами субъектов Российской Федерации // Российская юстиция. 2018. № 5. С. 9 - 13.

4. Проект «Кодекс Российской Федерации об административных правонарушениях» подготовлен Минюстом России, ID проекта 02/04/05-20/00102447 [Электронный ресурc] URL: https://regulation.gov.ru/ по состоянию на 29.05.2020 (дата обращения 31.03.2021).

5. Закон Вологодской области от 08.12.2010 № 2429-03 (ред. от 09.11.2020) «06 административных правонарушениях в Вологодской области» // Красный Север. 11.12.2010. № 139.

6. Областной закон Новгородской области от 01.02.2016 № 914-03 (ред. от 01.02.2021) «0б административных правонарушениях» // Новгородские ведомости (официальный выпуск). 05.02.2016. № 3.

7. Областной закон Ленинградской области от 17.07.2017 № 47-0з (ред. от 06.04.2020) «0 регулировании отдельных вопросов розничной продажи электронных систем доставки никотина, оборота никотинсодержащей продукции на территории Ленинградской области и о внесении изменений в областной закон «0б административных правонарушениях» // Официальный интернет-портал Администрации Ленинградской области http://www.lenobl. ru, 17.07.2017. утратил силу.

8. Федеральный закон от 31.07.2020 № 303-Ф3 «0 внесении изменений в отдельные законодательные акты Российской Федерации по вопросу охраны здоровья граждан от последствий потребления никотинсодержащей продукции» // Собрание законодательства РФ. 03.08.2020. № 31 (часть I), ст. 5062.

9. Апелляционное определение Судебной коллегии по административным делам Верховного Суда Российской Федерации от 19.06.2019 № 1-АПА19-4 06 оставлении без изменения решения Архангельского областного суда от 06.02.2019, которым была признана недействующей статья 5.4 Закона Архангельской области от 03.06.2003 № 172-2203 «0б административных правонарушениях» (ред. от 20.12.2018) // Документ опубликован не был.

10. Уставный закон Калининградской области от 01.12.2020 № 484 «0 внесении изменений в Устав (Основной Закон) Калининградской области» // Комсомольская правда - Калининград. 11-12 декабря, 2020. № 142-143-с.

11. Уставный закон Калининградской области от 01.12.2020 № 485 «0б упразднении Уставного Суда Калининградской области и признании утратившими силу отдельных законодательных актов Калининградской области» // Комсомольская правда - Калининград. 11-12 декабря, 2020. № 142-143-с.

12. Закон Калининградской области от 12.05.2008 № 244 (ред. от 03.03.2021) «Кодекс Калининградской области об административных правонарушениях» // Калининградская правда. 21.05.2008. № 89.

13. Закон Псковской области от 04.05.2003 № 268-03 (ред. от 28.12.2020) «06 административных правонарушениях на территории Псковской области» // Псковская правда. 14.05.2003. № 85.

14. Закон Псковской области от 28.12.2018 № 1915-03 «0 Гербе Псковской области» // Псковская правда. 11.01.2019. № 2.

15. Закон Псковской области от 28.12.2018 № 1916-03 «0 Флаге Псковской области» // Псковская правда. 11.01.2019. № 2.

16. Закон Псковской области от 11.11.2019 № 2002-03 (с изм. от 09.12.2019) «0 Гимне Псковской области» // Псковская правда. 15.11.2019. № 46.

17. Закон НАО от 29.06.2002 № 366-03 (ред. от 04.12.2020) «06 административных правонарушениях» // Няръяна Вындер. 19.07.2002. № 116.

18. Закон Вологодской области от 03.05.2018 № 4334-03 «0 внесении изменения в закон области «0б административных правонарушениях в Вологодской области» // Красный Север. 05.05.2018. № 47. 